Article

\title{
Decisions on Recycling or Waste: How Packaging Functions Affect the Fate of Used Packaging in Selected Swedish Households
}

\author{
Helén Williams ${ }^{1, *(\mathbb{D}}$, Fredrik Wikström ${ }^{1} \mathbb{D}$, Katarina Wetter-Edman ${ }^{2} \mathbb{D}$ and Per Kristensson ${ }^{3}$ \\ 1 Service Research Center and Department of Engineering and Chemical Sciences, Karlstad University, SE-651 \\ 88 Karlstad, Sweden; fredrik.wikstrom@kau.se \\ 2 School of Business, Örebro University, 70281 Örebro, Sweden; Katarina.Wetter-Edman@oru.se \\ 3 Service Research Center and Department of Social and Psychological Studies, Karlstad University, SE-651 88 \\ Karlstad, Sweden; per.kristensson@kau.se \\ * Correspondence: helen.williams@kau.se; Tel.: +46-54-700-1850
}

Received: 3 October 2018; Accepted: 11 December 2018; Published: 15 December 2018

\begin{abstract}
The intention of this paper is to learn more about why consumers choose whether or not to recycle, with special attention given to the functions of the packaging itself, in order to provide suggestions for improvements in packaging design, recycling systems and the environmental assessment of different packaging designs. The study focussed on ten households in Sweden that where motivated to participate in the study in order to gain an understanding of the complex matter of this decision-making process. The intention of implementing an interview-based qualitative study was to gain rich data and to reach beyond the respondents' immediate verbal responses. The respondents were interviewed with open-ended questions, which were supported with pictures of packaging; additionally, their waste bins were examined. This explorative study suggests a set of obstacles that cause consumers to dispose of packaging relating to the functions of packaging. The different obstacles that determine whether or not packaging is recycled were organised according to three different themes: the attitude towards cleanliness, the effort required to clean and sort and uncertainties about the best environmental alternative. The different functions of packaging do in fact influence all of the identified themes and; therefore, influence the decisions consumers make with regards to the recycling of specific packaging. The identified packaging functions were easy to separate different materials, easy to separate different parts, easy to clean, easy to empty, easy to reseal, easy to compress and communication regarding recycling. Consumer behaviour with regards to specific packaging functions and recycling should be further investigated. It should also be considered for inclusion in design processes, to increase the chance of materials being recycled, and in food-packaging life-cycle assessments, to provide results that align more closely with reality.
\end{abstract}

Keywords: packaging waste; packaging functions; environmental impact; content properties; behaviour; attitudes

\section{Introduction}

This paper aims to explore the extent to which different packaging functions influence a consumer's decision whether to sort packaging for material recycling purposes or to dispose of the packaging as waste.

To achieve the aims of the EU circular economy package [1], efforts are needed to improve packaging design, collection (including public participation) and recycling systems in order to reduce the material losses of packaging materials in both quantitative and qualitative terms. Significant progress has been made in Sweden to increase collection and recycling rates during the last decades [2]. 
However, the quality of the recycled material is often too low to replace virgin materials. The recycling rate for plastics in Sweden is 53\%, according to official statistics. However, $84 \%$ of the collected plastics are used for energy recycling or are deposited. The remaining $16 \%$ is used for material recycling and is sold at $50 \%$ of the value of virgin materials because of its lower quality [2]. For plastic packaging, only $20 \%$ is collected from households and the remaining $80 \%$ is waste, which is sent to energy recycling plants [3,4]. The solution to this problem has so far been to use the material for energy recycling or export it to other countries, for example, in the Far East [5].

This means that there are significant economic losses, emissions from energy recycling and that new virgin materials must be produced. This example shows that there is a need to address not only the quality of the recycled materials, but also the quantities recycled.

The packaging must be collected for recycling after use, which presupposes consumer participation. The convenience for the consumer to recycle has long been recognised as an important factor in increasing recycling rates (for example, [6-8]). This includes collection systems, but also the easiness of sorting packaging in households.

A common strategy to favour the convenience of the consumer is that packaging is collected dirty and/or mixed in different ways [5]. This may increase the percentage of packaging collected, but on the other hand means that larger efforts in terms of energy and economy are needed to sort packaging, both manually and automatically, in the recycling industry. Additionally, as far as the authors of this paper understand, there is still an open question as to whether this kind of system will be able to achieve a quality of recycled materials which is sufficient for them to be able to replace virgin materials. Moisture and organic material may affect the quality of plastics [9] and can certainly affect paper packaging. However, detailed accounts of the quality of recovered materials are scarce in published literature [5].

The Swedish strategy is to involve consumers in the recycling process. Consumers are expected to clean packaging, sort it into mono-streams and take it to different collection sites (for a detailed description of the Swedish system and policy instruments, see Henriksson et al. [10] and Finnveden et al. [11]). One advantage of this system might be that organic residues are removed to a higher extent since consumers often store the packaging inside their homes and want to avoid unwanted smells, which allows for higher quality of recycled material. One disadvantage is that it is an easy option to put packaging into the waste bin, thus saving the work effort required to handle the packaging and take it to the collection sites. In this kind of system, it is essential to understand how consumers act and how packaging should be designed to facilitate convenient handling for the consumer. This is the topic of this paper, which will be further developed in the following sections.

There have been many studies on the importance of collection systems (for example, [12-14]), attitudes to recycling and social norms (for example, [13,15-17]) and uncertainty about how and what to sort [10], to mention a few. However, there has been less attention paid to the artefact itself: the packaging. However, in a recent study, consumers indicated that they would like fewer and better packaging materials and plastic packaging that could be recycled without a decrease in quality [18]. It is well known that products functions can influence user behaviour [19-21]. It seems highly likely that this is also true for packaging and consumer recycling. With this in mind, there are surprisingly few studies that examine this area.

Langley et al. [22] published pioneering work on how packaging design influenced recycling in a British context. They examined packaging material, geometry, information and the contents of the packaging with regards to recycling. Their results showed that the perceived value of the material was an important factor for the respondent's decisions; for example, glass had a high value and plastics had a low value. Functions such as resealable packaging also increased the perceived value. Flat formats without any secondary use were perceived as having a low value. The effort and time required to prepare the packaging for recycling, for example to clean a package, was also an important factor. The recycling facilities available within the household and whether the handling of the contents of the packaging was perceived as undesirable were other influencing factors. Their study 
has served as an inspiration to this work, although the focus is on the functions of the packaging that consumers experience.

The intention of this paper is to learn more about how consumers choose whether or not to recycle, with special attention given to the functions of the packaging itself, in order to provide suggestions for improvements in packaging design, recycling systems and the environmental assessment of different packaging designs. Decisions made about the recycling of packaging are based on more than attitudes, behaviour, organisations, systems or materials. It is posited that the specific packaging design, along with its functions, is important for the consumer decision on whether or not to sort the package for material recycling.

This explorative study is based on interviews in households. The interviews were designed with the assumption that people are generally unaware of the connection between their behaviour and packaging functions $[23,24]$. The interviews in the households were complimented with an unexpected bin inspection, with the purpose to double-check and further investigate their answers, as respondents can tend to give socially acceptable answers [20].

The paper proceeds as follows. First, the theoretical framing for the understanding of consumer behaviour in relation to products is presented. Secondly, packaging functions are presented that may influence decisions on whether or not to sort. The sample of respondents and their socio-demographic profiles are followed by a presentation of the data collection methods, analysis and results. Finally, the relevance of the results in regards to implications for packaging design, environmental assessments of packaging, policies and the need for further research are discussed.

\section{Materials and Methods}

\subsection{Theoretical Framing}

This study relies on psychological notions in order to understand the reasons for the respondents' behaviour. Kollmuss and Agyeman [25] suggest that pro-environmental behaviour is influenced by internal factors (for example, knowledge, values and attitudes, emotions, motivation and locus of control) and external factors (for example, infrastructure, social and cultural factors, and the economic situation). Research in social psychology confirms that individuals with strong positive attitudes towards environmental issues do not directly translate their attitude into similar actions. This can be due to various obstacles, such as the fact that eco-friendly alternatives may be more costly or time-consuming. There may also be obstacles with regard to the social dilemma that some people may undertake the task of sorting and recycling packaging, while other consumers in the same community may not [20], which can lead to a reduced inclination to engage in pro-environmental behaviour among the former.

The functions of the packaged product itself also represent an important obstacle to recycling. Notably, among the affective, behavioural and cognitive factors proposed by Kollmuss and Agyeman [25], and mentioned above, the effect of the artefact itself is lacking. However, the package as an artefact is likely to play a significant role in the user experience. Within marketing, there is a need to attend to the many kinds of value-creation processes experienced by users in order to develop an offering [26,27]. According to Jelsma [19], packaging provides different functions that offer pre-requisites for value-creation to occur and to be experienced by the users. It can be said that the product's functions may influence consumer behaviour. Consumer interaction with the product depends on its design, consumer preferences and their experience, and the context in which the consumer uses the product [28].

In conclusion, the decision to recycle a specific packaging depends upon a complex combination of individual attitudes, packaging functions and the collection system (which is outside the scope of this study). With this information at hand, one important task for the present article is to identify general functions related to packaging as well as to further explore the role of specific packaging functions and product properties in relation to behavioural intentions to recycle different kinds of packaging. 


\subsection{Packaging Functions Used in the Study}

We used packaging functions; see also [29-32]. The literature supported the idea that the following packaging functions may influence the decision to recycle or not.

Easy to empty. If there is food residue left in the packaging, then it will take time to clean it. This may also be perceived as disgusting for some products, such as bloody material [22]. In studies that examine waste bins, there is often some food left in the packaging [22,33,34].

Easy to clean. Even if the majority of the food has been emptied out of the packaging, some combinations of food and packaging leave food residues on the surface inside the package (e.g., high viscous products such as yoghurt). The consumer experience of the amount of effort required when cleaning the packaging, time stress and disgust can direct the package into the waste bin [22].

Containing the desired quantity. If the packaging contains more than the needs of the actual household, then it may become old and mouldy [32]. In this case, the packaging can be perceived as both time-consuming and disgusting to empty and clean [22].

Easy to compress. The storage space for sorting bins inside and outside the home is normally limited, and it has been found to be a barrier to recycling $[15,35]$. If it is possible to compress the packaging, then it will take up less space in the recycling bin.

Information on how to sort. Consumer uncertainty about how different materials should be separated is a common reason for packaging waste [10]. Uncertainty about how clean a package must be to be placed in the recycling bin is also an obstacle experienced by consumers [4]. Consumers do not take the time to look for instructions on the packaging about how to sort it, or it may be that the instructions are difficult to find or read [22]. There may be confusion concerning the different symbols in countries where symbols are used. Everyday sorting could also be habitual [10], and consumers may not want to spend the time looking up the information.

Easy to separate into different fractions. The time needed to recycle is often a hurdle [13]. In the study by Langley [22], mixed materials were recycled to a lesser extent. It can be expected that packaging that consists of several materials or different parts can be perceived as too time-consuming to separate. There can also be uncertainty about if separation is even necessary and how to sort the mixed materials [4].

Easy to reseal. The introduction of more functions, like resealability, may also provide an experienced higher value, and hence a higher motivation to recycle [22,36].

Besides the packaging functions in terms of the functions given above, the packaging's material type and mass are included in the study as they may influence the perceived value, for example glass is perceived to have a higher value than plastics [22]. However, from their study it is difficult to determine if the low experienced value of plastics depends on the material type or a lower mass, or a combination of the two.

\subsection{Selected Factors to Study}

From the literature above, and specifically Henriksson et al. [10] and Langley et al. [22], we concluded that the following factors influence the decision to recycle or dispose of packaging:

1. The attitude and knowledge of environmental issues, and readiness to participate in recycling;

2. The attitude towards disgusting content in the packaging;

3. The amount of effort (perceived work) required to recycle a specific type of packaging;

4. Uncertainty regarding waste handling;

5. Packaging functions;

6. The organisation of the overall recycling system in the household.

\subsection{Data Collection and Respondents}

A qualitative approach is useful when aiming to explore a fairly unknown subject area and where the dynamics and relations of a situation are of interest [37]. As concluded in the review above, the 
relation of users' attitudes to packaging functions, their recycling behaviour and how recycling is carried out in their homes in relation to specific packaging functions is largely uncharted.

Following the ambition to inform future packaging development, the study uses qualitative methods with inspiration from design research $[38,39]$. Within design research, data collection with real users in their particular context is conducted as a means to provide a richer and more dependable view on situations in which behaviour will occur [40]. Different types of data collection techniques will access different types of information. For example, regular interviews can access explicit knowledge, which is possible for users to articulate, interviews supported by objects (for example, pictures) may elicit a wealth of information about feelings and memories, and observations have the potential to access what users actually do in a particular situation [40-42].

In this study, three different interview techniques were used, which aimed to address different aspects of the respondents recycling behaviour and attitudes: (1) open-ended interviews allow the respondents to expand on the questions asked [43,44]; (2) probed interviews, where pictures are used to facilitate the discussion so that the respondent relies less on memories alone, with the purpose of making sure that the same objects are referred to in all interviews (see, for example, De Leon and Cohen [45]); and (3) a direct examination of the respondents' waste bins. This combined observations and interviews with the purpose to address potential discrepancies regarding what people say and their actual actions, and as such reach further into underlying attitudes or assumptions. The procedure for each of these techniques is described in detail below in Section 2.5 and the analysis is presented in Section 2.6.

Interviews were conducted with 12 respondents in 10 households in two Swedish municipalities, Karlstad and Hammarö. Karlstad is a city with approximately 85,000 inhabitants, and Hammarö has approximately 15,000 inhabitants. The two first authors of this article sent e-mails to around 30 people within their network, asking them to participate in a research study about the recycling of packaging and the possibility of visiting them. This resulted in respondents from 10 households agreeing to participate. Plans were made with the contact respondents for meetings, which would be later conducted in their homes. This means that the respondents were within a group of friends or acquaintances of the authors. All twelve of the respondents lived in their own houses. They all needed to travel to packaging collection sites. External factors, such as demographic, institutional (for example, distance of travel to collection sites) and economic factors, were similar for all respondents and they could all be classified as middle-aged, upper middle-class and educated to university level, which means that these parameters were outside of the scope of this study. There were two main considerations for the selected sample: first, the possible difficulty of finding families that were willing to have a researcher visit their home and discuss this matter; second, if there were packaging functions that hamper recycling among these well-educated respondents, supposedly having positive attitudes towards recycling and the environment, then it is likely that many other people also experience these obstacles. The respondents had very little information when the interviews commenced. It was communicated in the e-mails that the aim was to find out more about how packaging can be improved to be easier to recycle. Initially, the same information was presented to all respondents: "I and my colleagues have for many years been investigating how packaging can be designed to have a smaller ecological footprint. We have specifically looked into how packaging can be improved to help people to reduce food waste. In this new study we want to investigate if packaging is designed to be easy to recycle." This means that the packaging was intentionally blamed for any problems with recycling, rather than the respondents themselves. It was thought that this may assist them in giving open and honest responses.

Nine out of the ten participating households had children living at home. One family had children under the age of 6 and eight families had children between 9-17 years of age. In seven households the interviews were conducted with a female, in one family it was conducted with a male, and in two households both a male and female were interviewed. During interviews in households with two respondents from the same family, they often fell into each other's sentences and talked between them 
to form one answer to the same question. There were no disagreements between the two and thus these answers were viewed as one in the analysis. From this point in the article, the number of respondents is therefore 10. All of the interviews were conducted in the families' homes. The interviews lasted an average of 32 minutes.

The interviews were recorded, transcribed and analysed. In addition to this, the facilities for recycling and the waste bin were photo-documented as support for later analyses.

\subsection{The Interviews}

The first interview was inspired by ethnographic studies; open-ended questions were used to give the respondents the opportunity to answer in their own words [43]. The questions were about their attitudes and behaviour, differences in each family member's recycling participation (Q1-Q3) and how they organise recycling in their homes (Q4). In addition, the respondents were asked to show the contents of their recycling bins and comment on this (Q5). The intention of this exercise was to find out whether there are other reasons for their behaviour. Photographs were taken to document the recycling bins. There were open questions about packaging that was either rarely or never recycled, and the reasons for this behaviour (Q6-Q7). Respondents were also asked about any uncertainty when sorting different materials and how they find information on how to recycle (Q8). See questions in Table 1.

Table 1. The questions in the interview guide for the two interviews and the bin raid.

\begin{tabular}{|c|c|c|c|c|c|c|}
\hline \multirow{3}{*}{ Question } & \multicolumn{6}{|c|}{ Factor } \\
\hline & $I$ & $I I$ & $I I I$ & $I V$ & $V$ & $V I$ \\
\hline & $\begin{array}{l}\text { Attitude to the } \\
\text { Environment and } \\
\text { Participation in } \\
\text { Recycling }\end{array}$ & $\begin{array}{l}\text { Attitude to Any } \\
\text { Disgusting } \\
\text { Contents of the } \\
\text { Packaging }\end{array}$ & $\begin{array}{l}\text { Effort to } \\
\text { Recycle a } \\
\text { Specific } \\
\text { Packaging }\end{array}$ & $\begin{array}{l}\text { Uncertainty } \\
\text { Regarding } \\
\text { Waste } \\
\text { Handling }\end{array}$ & $\begin{array}{l}\text { Packaging } \\
\text { Functions }\end{array}$ & $\begin{array}{c}\text { Organisation of } \\
\text { the Recycling } \\
\text { System in the } \\
\text { Household }\end{array}$ \\
\hline $\begin{array}{l}\text { Q1. What are your thoughts } \\
\text { regarding recycling in general? }\end{array}$ & $x$ & & & $x$ & & \\
\hline $\begin{array}{l}\text { Q2. Do you think it is important to } \\
\text { recycle, why/why not? }\end{array}$ & $x$ & & & $x$ & & \\
\hline $\begin{array}{l}\text { Q3. Does everybody in your family } \\
\text { participate? Have you all got the } \\
\text { same standards? }\end{array}$ & $x$ & & & & & \\
\hline $\begin{array}{l}\text { Q4. Can you tell me about how } \\
\text { you organise your recycling? }\end{array}$ & & & & & & $x$ \\
\hline $\begin{array}{l}\text { Q5. For what kind of material do } \\
\text { you have a sorting bin? Can you } \\
\text { show me where they are and } \\
\text { comment on what we see? }\end{array}$ & & $x$ & $x$ & $x$ & $x$ & $x$ \\
\hline $\begin{array}{l}\text { Q6. Do you have packaging that } \\
\text { you find difficult to recycle? Why? }\end{array}$ & & $x$ & $x$ & $x$ & $x$ & \\
\hline $\begin{array}{l}\text { Q7. Do you have packaging that } \\
\text { needs to be cleaned? What do you } \\
\text { think about that? Does it influence } \\
\text { the recycling? }\end{array}$ & & $x$ & $x$ & $x$ & $x$ & \\
\hline $\begin{array}{l}\text { Q8. Is it difficult to decide by type } \\
\text { of material? Do you look for } \\
\text { information about how to recycle a } \\
\text { package on the internet? }\end{array}$ & & & $x$ & $x$ & $x$ & \\
\hline $\begin{array}{l}\text { Q9. I have } 8 \text { pictures to show you } \\
\text { of different packaging, and I want } \\
\text { you to tell me what you do with } \\
\text { these types of packaging after they } \\
\text { are empty and why? }\end{array}$ & & $x$ & $x$ & $x$ & $x$ & \\
\hline $\begin{array}{l}\text { Q10. (Bin raid) Can you please } \\
\text { comment on what we see in your } \\
\text { waste bin? Why has this packaging } \\
\text { been put here? }\end{array}$ & & $x$ & $x$ & $x$ & $x$ & \\
\hline
\end{tabular}

In the second interview, pictures of eight common food products in unopened packaging were presented to the respondents $(\mathrm{Q} 9)$. This approach was also used in the study by Singh and Ordoñez [46], where printed cards were used as a mediating object to enable the discussion. The products were five 
dairy products $(1 \mathrm{~L}$ of milk in liquid carton board with a twist-cap top; $1 \mathrm{~L}$ of yoghurt in two different designs of liquid carton board packaging with a twist-cap top; $2 \mathrm{dL}$ of crème fraiche in a plastic pack with an aluminium oblate and a plastic lid; $60 \mathrm{~g}$ of butter spread in a carton or plastic tray and an oblate and a plastic lid), two meat products (minced meat in a plastic tray and bacon in plastic film) and a $500 \mathrm{~g}$ roll pack for refillable jam in a plastic tube with aluminium clips. The products were selected because it was understood that they can cause problems for the consumer (according to the functions described in Section 2.2); they are made from materials that are recycled less [3,4], and they represent a number of potential packaging functions, have different materials or combinations of materials [22] or include food items that could be undesirable to handle (meat or sticky contents) [22]. The different samples of liquid board packaging were chosen because either the viscosities of the products or the design of the packaging differ. The respondents were asked about whether they recycled or disposed of the specific products and the reasons for their decisions. The pictures were shown both to help them link their behaviour with their reasoning for it, and to help them reflect on how the packaging functions influence their behaviour. They were asked what they do with the specific packaging when it is empty, and why they do this. This part was motivated by the experience that consumers are generally unaware of how packaging functions can influence their behaviour $[3,30]$.

Finally, the respondent's waste bin was examined. At the end of the interview the respondents were asked if they were willing to have the contents of their waste bin examined, in order to see if any further information could be gained regarding their recycling behaviour. They were all given the opportunity to reflect and a majority were somewhat embarrassed about what might be found in their bin. After some hesitation, all respondents agreed to have their waste bins studied. The waste bin was emptied onto a plastic cover, and the packaging was sorted into different materials. Then, the packaging types or items were discussed with the respondents (Q10) and photographed. This procedure had two purposes: the first was to discover the packaging and the aspects that had not been discussed during the first and second interviews; the second was to discuss the potential inconsistencies from the interviews to gain a deeper understanding of their recycling behaviour [19]. The respondents did not know about this aspect in advance of the interview and had no reason to suspect that this would occur.

\subsection{Analysis}

A theoretically informed qualitative analyses was carried out, using thematic analysis, based on the coding and construction of themes $[47,48]$. Braun and Clark argue that almost all analysis is essentially thematic; however, it is important to make previous assumptions and research positions explicit for evaluation of the research. The method does not require a rigorous technique such as in grounded theory, for example. It is important, however, to state positions and explicitly discuss choices and decisions made.

For example, in terms of coding, what counts as a theme must be made explicit, since the relative importance of codes is more important than their quantity; this is discussed in Section 3. Furthermore, it must be stated how the data set will be represented and whether the coding is inductive (strongly linked to the data) or theoretical, using predefined codes and driven by an analytical interest. Hayes (1997) proposes that a more reflexive approach to thematic analysis can be achieved through the use of theory to provide a priori direction [48]. As mentioned, this study is informed by previous studies in terms of constructing interview questions and an analytical framework.

According to Braun and Clark, there are six steps or phases of analysis: (1) becoming familiarised with the material, including factors such as transcriptions, (2) generating initial codes, (3) searching for themes, (4) reviewing themes, (5) defining and naming themes and finally (6) writing the report.

The interviews were conducted and transcribed. Table 2 presents the number of respondents who always, sometimes or never recycle a specific type of packaging. 
Table 2. Consumer's comments about identified factors (packaging functions, contents, effort and uncertainty about the best environmental alternative) that hamper recycling for eight products, and the number of responses from those who never, sometimes or always recycle the specific packaging.

\begin{tabular}{|c|c|c|c|c|c|c|c|}
\hline Product & $\begin{array}{c}\text { Comments about } \\
\text { Disgusting Content } \\
\text { (Factor II) }\end{array}$ & $\begin{array}{l}\text { Comments } \\
\text { about } \\
\text { Efforts } \\
\text { (Factor III) }\end{array}$ & $\begin{array}{c}\text { Comments about } \\
\text { Uncertainty of Best } \\
\text { Environmental } \\
\text { Alternative (Factor IV) }\end{array}$ & $\begin{array}{c}\text { Comments about } \\
\text { Packaging Functions } \\
\text { (Factor V) }\end{array}$ & $\begin{array}{l}\text { Never } \\
\text { Recycle }\end{array}$ & $\begin{array}{l}\text { Sometimes } \\
\text { Recycle }\end{array}$ & $\begin{array}{l}\text { Always } \\
\text { Recycle }\end{array}$ \\
\hline $\begin{array}{l}\text { Milk } 1 \mathrm{~L} \text { liquid } \\
\text { carton board, plastic } \\
\text { screw-cap }\end{array}$ & & $\begin{array}{l}\text { A lot of } \\
\text { work to } \\
\text { separate }\end{array}$ & & $\begin{array}{l}\text { Difficult to compress } \\
\text { Mix of materials } \\
\text { Difficult to separate } \\
\text { materials }\end{array}$ & 0 & 3 & 7 \\
\hline $\begin{array}{l}\text { Yoghurt } 1 \mathrm{~L} \text { liquid } \\
\text { carton board, plastic } \\
\text { top plastic } \\
\text { screw-cap }\end{array}$ & Sticky & $\begin{array}{l}\text { A lot of } \\
\text { work } \\
\text { A lot of } \\
\text { work to } \\
\text { separate } \\
\text { Work vs. } \\
\text { value }\end{array}$ & $\begin{array}{l}\text { Needs a lot of water } \\
\text { Can be combusted }\end{array}$ & $\begin{array}{l}\text { Difficult to clean } \\
\text { Difficult to compress } \\
\text { Mix of materials } \\
\text { Difficult to separate } \\
\text { materials }\end{array}$ & 6 & 1 & 3 \\
\hline $\begin{array}{l}\text { Yoghurt } 1 \mathrm{~L} \text { liquid } \\
\text { carton board brick } \\
\text { package }\end{array}$ & Sticky & $\begin{array}{l}\text { Work vs. } \\
\text { value }\end{array}$ & $\begin{array}{l}\text { Needs a lot of water } \\
\text { Can be combusted }\end{array}$ & Difficult to clean & 4 & & 6 \\
\hline $\begin{array}{l}\text { Crème fraiche } 2 \mathrm{dL} \text {, } \\
\text { rigid plastic box } \\
\text { and plastic, lid, } \\
\text { oblate plastic }\end{array}$ & Sticky & & Needs a lot of water & $\begin{array}{l}\text { Difficult to clean } \\
\text { Several parts } \\
\text { Mix of materials }\end{array}$ & 3 & 3 & 4 \\
\hline $\begin{array}{l}\text { Butter spread, } \\
\text { plastic, rigid, wrap } \\
\text { of metal or plastic }\end{array}$ & $\begin{array}{l}\text { Sticky } \\
\text { Fatty }\end{array}$ & $\begin{array}{l}\text { Work vs. } \\
\text { value }\end{array}$ & $\begin{array}{l}\text { Needs hot water } \\
\text { Need detergent } \\
\text { Can be combusted }\end{array}$ & $\begin{array}{l}\text { Difficult to clean } \\
\text { Several parts } \\
\text { Mix of materials }\end{array}$ & 9 & & 1 \\
\hline $\begin{array}{l}\text { Jam* in plastic roll } \\
\text { pack, metal clips, } \\
\text { non-rigid }\end{array}$ & Very sticky & & & $\begin{array}{l}\text { Difficult to clean } \\
\text { Little material/low } \\
\text { value }\end{array}$ & 10 & & \\
\hline $\begin{array}{l}\text { Minced meat in } \\
\text { plastic tray, rigid. }\end{array}$ & $\begin{array}{l}\text { Disgusting-meat } \\
\text { Afraid of smelly } \\
\text { packaging after } \\
\text { cleaning }\end{array}$ & & Need detergent & & 4 & 1 & 5 \\
\hline $\begin{array}{l}\text { Bacon in plastic } \\
\text { packaging, } \\
\text { non-rigid }\end{array}$ & $\begin{array}{l}\text { Disgusting-meat/fat } \\
\text { Afraid of smelly } \\
\text { packaging after } \\
\text { cleaning }\end{array}$ & & Need detergent & $\begin{array}{l}\text { Difficult to clean } \\
\text { Little material/low } \\
\text { value }\end{array}$ & 9 & & 1 \\
\hline
\end{tabular}

* The actual discussion about this product turned out to be much more about rice pudding than jam, offered in the same type of roll packaging.

The interview transcripts from Q1-Q9 were kept together, whereas the bin examination (Q10) was analysed separately with a focus on why packaging is not being recycled. The procedures were the same.

The first step, according to Braun and Clarke [49], was to become familiarised with the data while noting initial ideas about the content. In the second step, the data extracts were coded and the data for each code was coupled with the data extracts and the codes; the codes were inspired by the literature review and factors I to VI; however, with an open mind for new codes that may influence recycling.

In the third step, potential themes were examined from the insights (What are the main themes? How are the themes connected to the factors? Are there any new factors?). Then, thematic maps were created during the fourth step as part of the analysis and the themes were reviewed. In the fifth step, the themes were refined and renamed, which is discussed in Section 3, and finally presented in the present text.

\section{Results}

The respondents stated their decision on whether or not to recycle for the eight products that where shown in the pictures $(\mathrm{Q} 9)$. The respondents highlighted several of the identified factors in Table 1 as reasons for not recycling packaging (see Table 2).

There was a wide range of obstacles to recycling. Packaging was not recycled because the product stuck to the material and the packaging needed to be cleaned before it could be put into the recycling bin. The packaging was always disposed of when it was difficult to clean and had a low weight, such as the packaging used for the bacon and jam. 
Packaging that consisted of several parts and/or a mixture of materials was another obstacle. Butter spread packaging consists of several parts of different materials. In addition, its surface is fatty and needs to be cleaned, which in combination results in very low recycling rates. The yoghurt with a plastic lid consists of more than two materials that are difficult to separate. One respondent interpreted the yoghurt packaging with a plastic top as being entirely plastic. No one mentioned the need to separate the metal clips from the jam's packaging, probably because this packaging was mostly disposed of.

Several of the respondents mentioned that the difficulty to compress packaging influenced their recycling, and this is one explanation for why yoghurt in carton board with a lid is recycled less frequently than yoghurt in a brick-format carton board.

The time required for cleaning the packaging was often mentioned as something that would influence recycling. If cleaning, drying and compressing took too much time, then the packaging would most likely be put into the waste bin.

Nine out of ten respondents reflected on the need to use water to rinse, and how much water is necessary to clean the packaging and questioned if that was good for the environment. Some also commented on the need to use hot water and detergents to clean it, and that this may require too many resources. Several also mentioned that packaging put into waste bins will be energy recovered, and therefore it does not matter if the packaging is not recycled. Some expressed uncertainty about what the best alternative was with regards to the environment.

Several respondents questioned if it was worth recycling both from an environmental point of view and from the amount of effort required for some of the different types of packaging. A significant factor in the decision to recycle was whether or not it was undesirable to handle the contents.

The respondents answers in the interviews where summarised and coded (see Table 3).

The comments about packages found in the bin raid, and the corresponding codes are shown in Table 4, some pictures from the bin raid are shown in Figure 1.

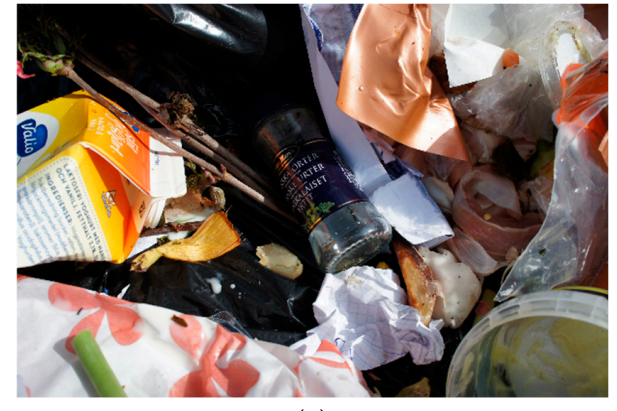

(a)

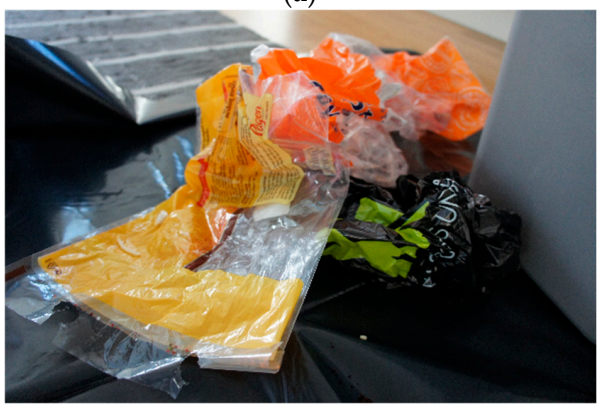

(c)

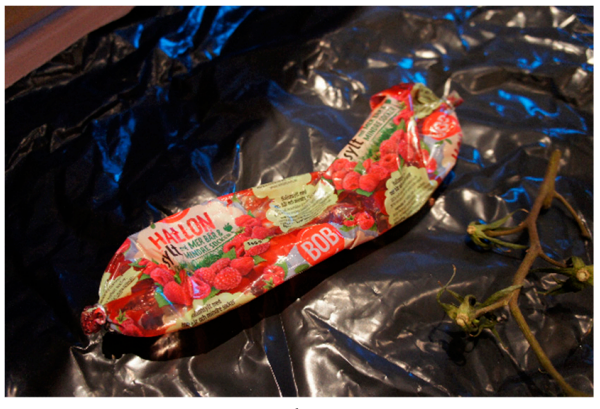

(b)

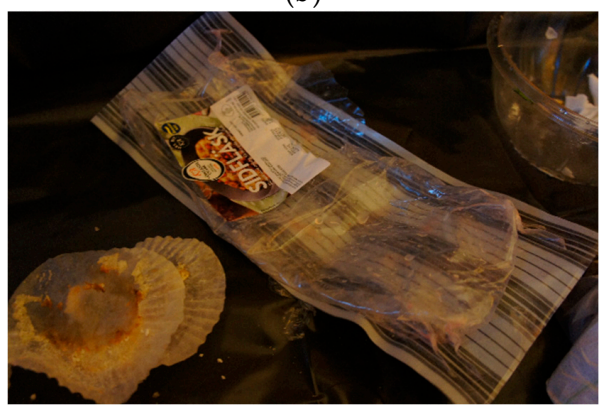

(d)

Figure 1. Pictures of some packaging found in the waste bin raid in four of the households. (a) soft and rigid plastic, liquid packaging board, glass jar; (b) jam packaging; (c) soft plastic packaging; (d) soft plastic and paper for bun. 
Table 3. The codes and examples of the data extracts from the interview transcripts. Q1-Q8. (Translated from Swedish).

\begin{tabular}{|c|c|}
\hline Code & Data Extract, Examples \\
\hline $\begin{array}{l}\text { Saving the } \\
\text { environment and } \\
\text { resources (Factor I) }\end{array}$ & $\begin{array}{l}\text { "The world's resources are diminishing, so, of course, you should participate." (R3) } \\
\text { "The most important reason is to save the environment and the resources that we have." (R5) } \\
\text { "It is important to get the things into the recycling system to make us resource efficient." (R9) }\end{array}$ \\
\hline $\begin{array}{l}\text { Content disgusting } \\
\text { (Factor II) }\end{array}$ & $\begin{array}{l}\text { "The sticky part is not so bad, but blood feels unhygienic-a little disgusting." (R1) } \\
\text { "Disgusting, sticky and meat products." (R5) } \\
\text { "Waste the rice pudding packaging, here we can talk about stickiness and therefore without a bad conscience, } \\
\text { which you can feel if you waste the liquid packaging board." (R7) } \\
\text { "When a product like crème fraiche is mouldy, I throw it away."(R10) }\end{array}$ \\
\hline $\begin{array}{l}\text { Content smelly or } \\
\text { fatty (Factor II) }\end{array}$ & $\begin{array}{l}\text { "I have to clean it to minimise the smell, and I do not do that." (R5) } \\
\text { "We rinse it, and then put the lid on to avoid a smell." (R6) } \\
\text { "Fat in the pipes of the house can be a problem." (R10) }\end{array}$ \\
\hline $\begin{array}{l}\text { Amount of effort } \\
\text { (Factor III) }\end{array}$ & $\begin{array}{l}\text { "Rinsing is OK, but if I have to use a brush it takes too much time (R1) } \\
\text { "“If it is easy to clean, then we do it, otherwise we do not." (R2) } \\
\text { "It is a lot of activities to clean, press, store, transport and throw it into a recycling container. It takes time." (R3) } \\
\text { "It is a lot of work and I feel lazy about it, it has to do with the time it takes." (R7) } \\
\text { "As soon as you get uncertain if it will take more time, then it goes to waste and incineration." (R10) }\end{array}$ \\
\hline $\begin{array}{l}\text { Uncertainty } \\
\text { regarding the best } \\
\text { environmental } \\
\text { alternative } \\
\text { (no factor) }\end{array}$ & $\begin{array}{l}\text { "Recycle without rinsing, the environmental gain is lost if it is rinsed." (R2) } \\
\text { "It is difficult to know what is best for the environment." (R3) } \\
\text { "If I have to rinse, then I do not know what is best for the environment." (R7) } \\
\text { "Using too much water for cleaning is not good for the environment." (R8) } \\
\text { "Will waste get used in combustion?" (R9) } \\
\text { "It probably costs less to burn than it does to clean." (R10) }\end{array}$ \\
\hline $\begin{array}{l}\text { Information on how } \\
\text { to sort (Factor V) }\end{array}$ & $\begin{array}{l}\text { "I do not think that I have seen any information about recycling on packaging." (R1) } \\
\text { "If there is no information, it goes to combustion." (R2) } \\
\text { "I would not look, I would waste it." (R6) } \\
\text { "If I had packaging that I was uncertain of, I might look for information, but, more likely, I would just waste } \\
\text { it." (R9) }\end{array}$ \\
\hline $\begin{array}{l}\text { Easy to separate } \\
\text { into different } \\
\text { fractions (Factor V) }\end{array}$ & $\begin{array}{l}\text { "Mixture of materials, and therefore combustion." (R3) } \\
\text { "In the morning when you are stressed, and you have to cut away the plastic on a yoghurt package, I do not like } \\
\text { that." (R5) }\end{array}$ \\
\hline $\begin{array}{l}\text { Several parts } \\
\text { (Factor V) }\end{array}$ & $\begin{array}{l}\text { "I do not like it when packaging should be put into two separate places. Then the largest part goes to the } \\
\text { recycling but not the lid." (R4) } \\
\text { "We rinse it and then put the lid on to avoid a smell." (R7) } \\
\text { "Glass bottles with oil are recycled without cleaning, since they have a lid it will not come out." (R6) }\end{array}$ \\
\hline $\begin{array}{l}\text { Packaging material } \\
\text { and mass (Factor V) }\end{array}$ & $\begin{array}{l}\text { "There are a lot of habits regarding what I recycle and do not recycle" (R6) } \\
\text { "Glass bottles will be recycled without rinsing-it should be OK in the recycling. I feel it is difficult to waste } \\
\text { glass." (R4) } \\
\text { "Bacon packaging goes to waste, it is too sticky and there is not much material." (R8) } \\
\text { "I don't think I have thought about if it is possible to recycle soft plastic." (R10) }\end{array}$ \\
\hline $\begin{array}{l}\text { Easy to compress } \\
\text { (Factor V) }\end{array}$ & $\begin{array}{l}\text { "I do not compress the packaging as I do not have the time. I prefer to take it more often to the recycling places, } \\
\text { they are close." (R1) } \\
\text { "At the recycling there are comments about how the packaging should be pressed and flattened, and they are } \\
\text { difficult to flatten." (R3) } \\
\text { "Press it to make it less bulky." (R4) } \\
\text { "I would like to have something that helps me to press the soft plastic to make it smaller in volume." (R8) }\end{array}$ \\
\hline $\begin{array}{l}\text { Messy in the } \\
\text { kitchen (No factor) }\end{array}$ & $\begin{array}{l}\text { "I do not like it when it is messy." (comment about having empty packaging in the sink, author) (R3) } \\
\text { "I put it under the sink in boxes." (R5) }\end{array}$ \\
\hline
\end{tabular}


Table 4. Packaging found in the waste bin raid for the respondents No. 1-10; and the data extracts from the transcripts and the codes from the interview (Q10). (Translated from Swedish).

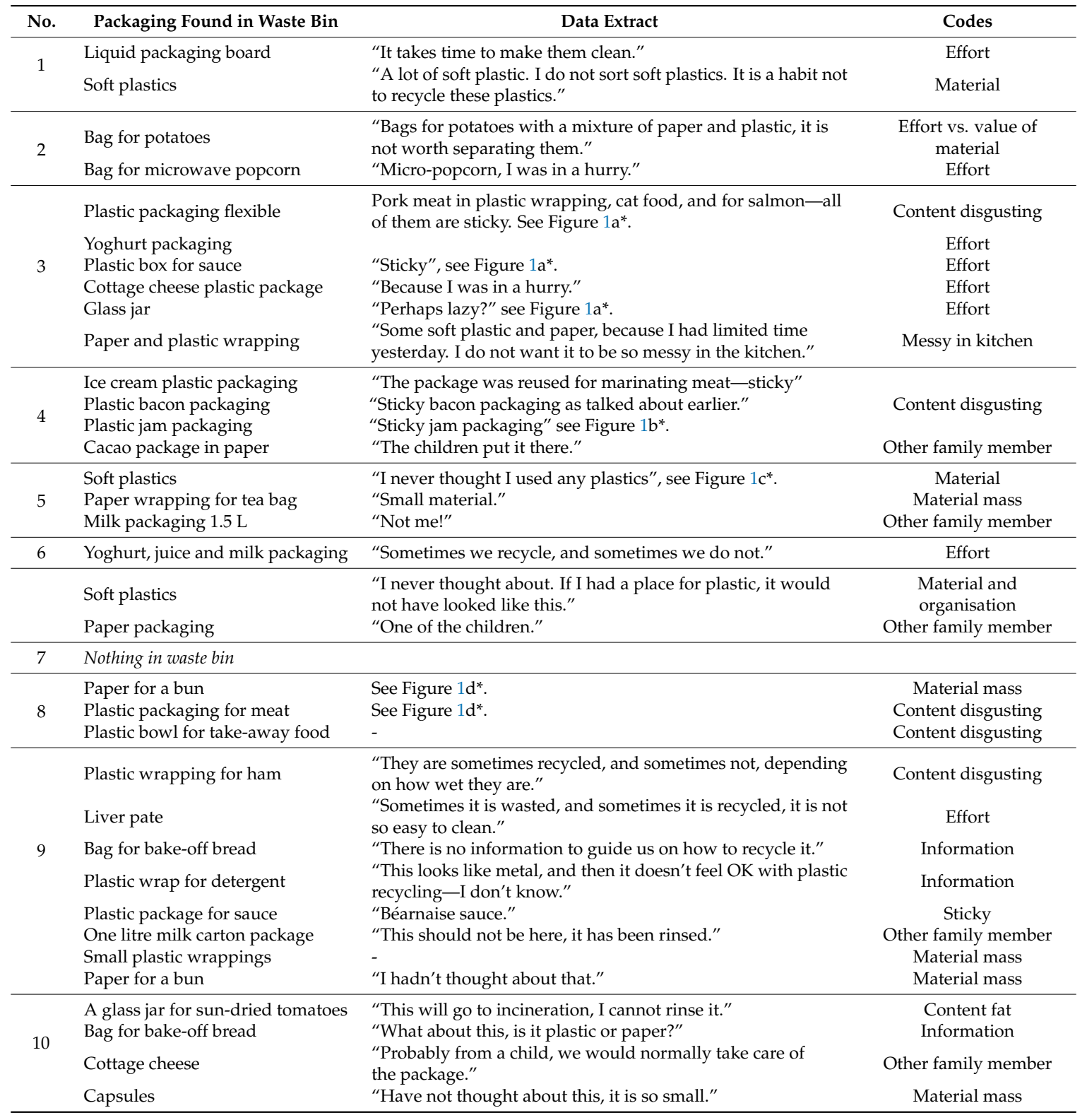

* Pictures are presented in Figure 1.

The results show that similar obstacles to recycling are addressed in all of the three tables. New perspectives about both the factors and the packaging functions are expressed and further addressed below.

All of the respondents recycled packaging because of their concerns for the environment. Saving resources was commonly mentioned. The obstacle of uncertainty became clearer during the interviews. They expressed uncertainty about how clean and how dry packaging must be in order to be recycled. These aspects were often discussed in relation to packaging with a higher mass (e.g., the liquid packaging board) and for the rigid plastic packaging, but not for the plastics with a low weight or with very sticky contents. Some pictures from the bin raid are shown in Figure 1.

Some respondents prefer a neat and tidy kitchen, and they do not like empty packaging being left to dry on the sink; this influenced them to put somewhat dirty packaging into recycling or to simply discard it, such as soft and rigid plastic and liquid packaging board as shown in Figure 1a and a sticky jam packaging in Figure 1b. The Figure 1c shows a lot of soft plastic packaging, and this respondent 
surprisingly said, "I never thought I used any plastics". Figure $1 \mathrm{~d}$ shows soft plastic and paper for bun. Two of the respondents mentioned that they wanted to avoid pouring fatty products into the sink since it could cause problems by clogging up the drains and; therefore, they did not rinse and recycle these types of packaging. If the packaging had a low mass or part of the packaging had a low mass, such as lids or plastic wrappers, the respondents did not regard it as meaningful enough to recycle it, stating for example, "I do not like it when it should be put into two places. Then the largest part goes to the recycling, but not the lid." Even respondents with recycling bins close to the sink in their kitchen said that different parts were an obstacle. Both low mass and the need for separation of materials can decrease the chances of recycling packaging. See the example in Figure 1d, a small paper for a bun. However, some respondents kept the lid until they took it to the recycling station. The lid prevented an odour escaping from the recycled packaging, and it also stopped liquid, such as milk or water after rinsing, from leaking into the recycling bins and causing an inconvenience. Therefore, the lid reduced the obstacles for some of the respondents.

The amount of effort required was mentioned, together with recycling in general, and in close relation to several packaging functions. With regards to the glass jar in Picture (Figure 1a), the respondent explained by saying they were "perhaps lazy". The consumers mentioned seven out of the eight specified packaging functions. The function not mentioned specifically was containing the desired quantity; however, one respondent threw away a mouldy crème fraiche container, which may depend on that function. When the product was mouldy the product and packaging were disposed of together, since it was disgusting to empty.

The respondents answered that they seldom used the information regarding recycling that is printed on the packaging. No respondent had ever looked for information regarding recycling on the Internet.

In the interview during the bin raid, the respondents sometimes gave their children's behaviour as an explanation for why some of the packaging had ended up in the waste bin. The respondents said that there were small differences in how the adults act, though most often this was not a cause of conflict.

Regarding organisation (Q4), the households recycled carton board, plastic, metal and glass, and several of the respondents did not recycle non-rigid plastics such as bags and wrapping. The respondents sorted their packaging into two main areas, the kitchen (under the sink, in a cupboard or in a corner) or in a room close to the kitchen (a laundry room or on the stairs to the basement). No respondent mentioned the organisation and location of the recycling bins as an obstacle for recycling.

\section{Development of a Map for Recycling Trade-Offs}

Through the work with the analytical themes, a final thematic map was created whereby the consumer decision to the question "Should I recycle or not?" was placed at the top (see Figure 2). The decisions the respondents made about recycling were complex compromises. The identified themes were environmental evaluation, effort required and cleanliness.

Within the environmental evaluation theme, four categories were found: sabotage of the recycling system, the amount of resources used for cleaning, the value of the material and the idea that combustion provides energy. In this theme, the respondents expressed the greatest uncertainty. The respondents judged the negative environmental effects (for example, using water and detergents, or the risk of sabotage of the recycling system) versus the positive effects of recycling. Their knowledge of unsorted packaging being combusted to recover energy affected their judgement. Several aspects related to the packaging functions were identified, such as mixed materials, a lack of information on how to sort recycling and the resources used to clean the packaging. 


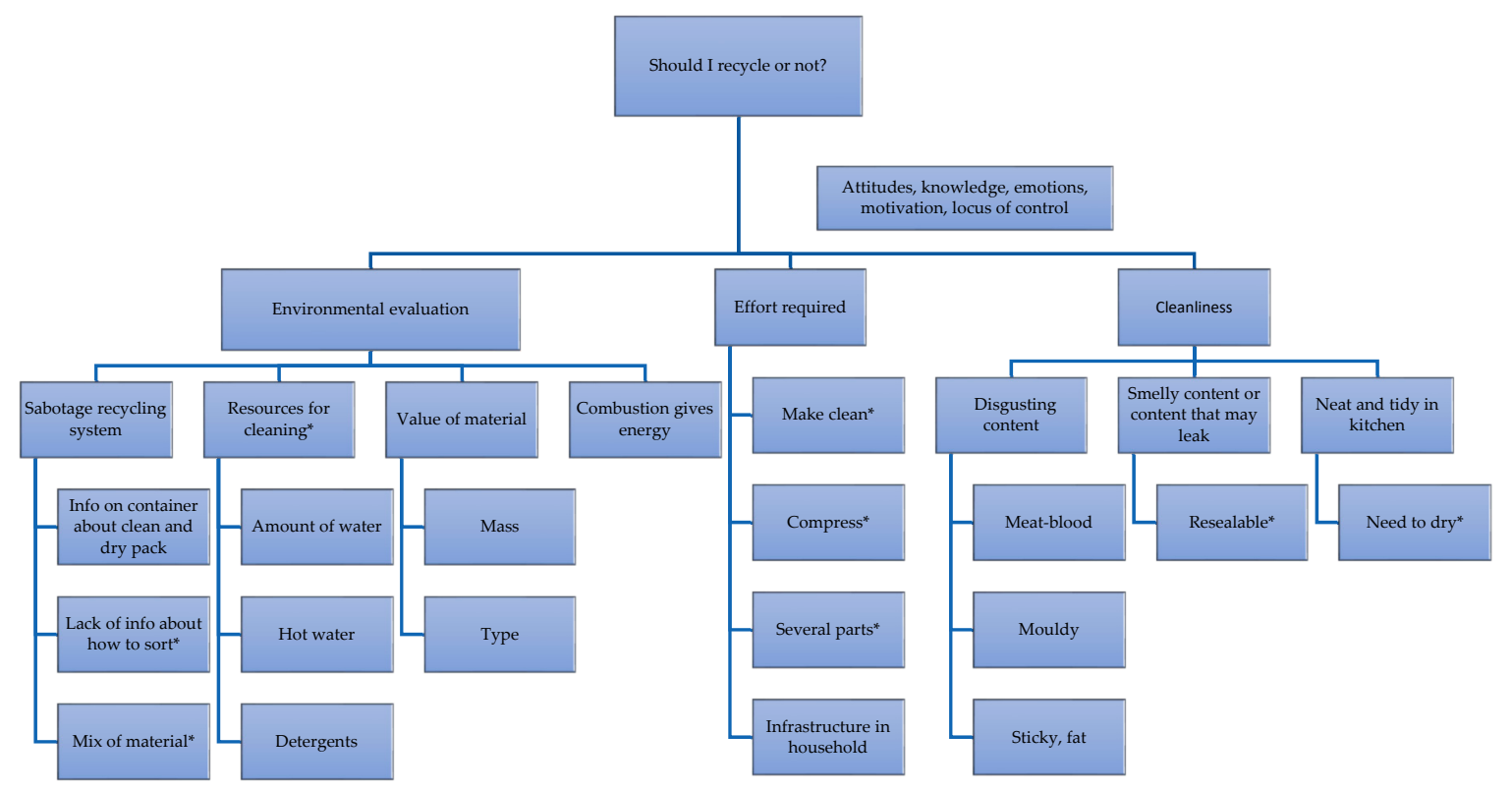

Figure 2. A map of the recycling decision with three themes (environmental evaluation, effort required and cleanliness), with different aspects that may be included in compromises that people consider when they decide whether or not they should recycle a specific item (aspects that are related to the functions of the packaging are marked with an *).

The theme effort required consists of several aspects that are related to the functions of the packaging: being easy to clean, being easy to compress and being constructed with several different materials or parts that need to be separated. The effort required was, to a minor extent, also influenced by how the recycling of the packaging had been organised in the household.

In the third theme, cleanliness, three aspects were identified: handling of contents being undesirable, contents being smelly or contents that can leak, as well as wanting to keep a neat and tidy kitchen. Contents which were undesirable to handle were described as meat and blood, as well as mouldy, sticky or fatty products. These contents could be considered as smelly or having the potential to leak out of the packaging, but the function of resealable packaging could reduce both effects. Some respondents said that they do not like the kitchen to look messy when the packaging has been left out to dry on the sink. The respondents that find the handling of contents to be undesirable or dislike their kitchen looking messy were found to always direct the packaging to the waste bin.

\section{Discussion}

This study shows, in accordance with earlier studies, that the decision as to whether or not to recycle is a complex matter. The functions of the packaging and the product properties are intertwined with emotions, attitudes and knowledge. The respondents' decision on whether or not to sort packaging for recycling depends on their assessment of environmental benefit, work effort and aspects of cleanliness. Several packaging functions, particularly easy to clean and easy to separate into different fractions, were important factors for the factual behaviour.

The respondents' failure to recycle depended on a number of obstacles, whereby different obstacles ranged in level and importance for different respondents. The decision as to whether or not to recycle did sometimes depend on one obstacle, but more often depended on a combination of various obstacles.

If the handling of a product was perceived as being undesirable, for example, fresh meat with blood, those respondents disposed of the packaging with no regard for the quality of the packaging's functions. The need to dry the packaging (on the sink) was an obstacle for those that want their kitchen to look tidy. In those cases, it would be difficult for a packaging developer to overcome these obstacles by improving packaging functions. 
Some respondents were annoyed when the handling of a package was time-consuming or complicated. That reaction could, for example, have led to them recycling the biggest part, when the packaging consisted of several different parts. In this study, it became clearer that the function easy to separate into different fraction consists of two different functions. A mixture of material influenced the respondents' environmental evaluation, and uncertainty about sabotaging the recycling system; a function to strive for; therefore, is easy to separate different materials. Packaging consisting of several parts influenced the perceived level of work effort required; a function to strive for to reduce this; therefore, is easy to separate different parts.

Uncertainty about what is actually the best behaviour, for the environment, with different packaging was an obstacle for several of the respondents. A general attitude can be summarised as, "Recycling is important for the environment, and I want to do the right thing; however, I don't know what the right thing is." In the study by Henriksson et al. [10], confidence in the recycling system was one measure for taking an active part in the recycling process, and none of the respondents in this study spontaneously mentioned any lack of confidence in the system.

In summary, to increase the recycling rates among these respondents, it is not about improving their attitudes, but about removing, or reducing, the obstacles that have been identified. How this might be achieved is discussed in Sections 4.2-4.4. The relevance of the results is discussed in Section 4.1.

\subsection{The Relevance of the Results}

The interview format made it possible for a deeper understanding and dissociation of the role of packaging functions in the recycling decision process. As Crouch and McKenzie [37] suggest, it is the purpose of a small-scale interview-based study to be generative and to indicate promising areas for further exploration. In particular, the interview with pictures of different packaging formats (Q9) provided many product-specific insights, as differences were seen for very similar packaging. It is much easier to recall how a particular package is treated than to estimate how different packaging functions influence the decision in general. This is probably the reason why the results in this study are quite contradictory to an online survey where the majority stated that too much time and too much work effort were not important reasons to not recycle [17].

Packaging functions are factors to consider when analysing recycling behaviour and in design processes for new packaging that is easier to recycle.

As follows are some notes about the respondents that may have affected the results in this study and are important to explore further in new studies:

- The respondents in this study stated that they consider recycling to be important for the environment. Therefore, one can expect that other people, who care less about the environment, will regard some packaging functions as larger obstacles than these respondents. On the other hand, the design of the packaging functions may play less of a role for less motivated people that do not recycle for other reasons, such as long travel distances to the recycling centre.

- It is possible that the selected sample of households that were chosen (highly educated, high-income families with pro-environmental attitudes) actually overthink their environmental evaluations. The respondents admitted their uncertainty and stated that it would have been beneficial to actually know more. With less of a pro-environmental attitude, they might not think about sabotaging the recycling system with packaging containing food residues.

- One possible advantage to working with this group of households is that they may reflect upon the packaging functions and their own behaviour more deeply. Other studies, such as Langley et al. [22] and Fråne et al. [4], show a high discrepancy between what consumers say and do. The bin examinations in this study confirmed, to a large extent, what the respondents had already shared in their interviews. 


\subsection{Implications for Packaging Design}

Companies involved in packaging development may, to a higher extent, consider how packaging functions influence recycling decisions. A starting point could be to identify the obstacles that are associated with a specific product. At best, the obstacles could be removed, which mean increased convenience, and if not, the package could be designed with the best chances of consumer recycling behaviour in mind.

Generally, the packaging functions easy to empty and easy to clean are important to focus on in order to achieve improvements, as they influence all three of the themes: cleanliness, the effort required and environmental evaluation. The easy to separate different parts function is important; however, some consumers perceived packaging with several different parts as annoying no matter how easy they were to separate. Using a reduced number of material types in packaging would increase the possibility that the packaging will be recycled.

An interesting aspect highlighted in this study was that the easy to reseal function was used to keep moisture and odours inside the packaging and helped to increase recycling activity for those who were not eager to clean and dry them. This function was also mentioned in the study by Langley et al. [22], but in the sense of the packaging having a higher perceived value. However, the resealable aspect should preferably be made of the same material as the main packaging, see above.

If some important obstacles cannot be removed and the package cannot be expected to be recycled, an alternative strategy could be to minimise the environmental impact of the package in the waste stream. For example, a plastic tube for refillable jam will be disposed of very frequently, because it is very sticky and it has a fairly small amount of material. In such a case, the metal clips for closing it are unsuitable since they will create a higher environmental impact when they are burnt or deposited. Packaging should be easy to compress since respondents tended to mention that it is more important to compress when it is put into recycling; this probably has to do with transporting it by themselves to the recycling station and not wanting it to take up too much space.

\subsection{A Need for Better Information}

This group of well-educated people, with positive attitudes towards recycling and the environment, admitted a high level of uncertainty about the best choices, environmentally, and about their sorting practices, for example, how to clean and dry the packaging and how mixed materials should be handled. The producer's responsibility to collect and recycle packaging in Sweden has been in practice for more than twenty years. Our indications somewhat demonstrate the difficulties in strengthening the knowledge of best practice in recycling, thus governments and businesses can do better in communicating these issues. The consumers want to know that their recycling effort results in environmental improvements and that they do not sabotage the recycling system with improper sorting; therefore, the function communication about recycling is important. The most significant uncertainties among the respondents were:

- Is it good for the environment to wash the packages in warm water, or to use detergents if necessary? Or is it better to use the package for energy recycling?

- How clean and dry must packaging be? Does the information provided at the recycling stations, that only clean and dry packaging should be put into the container, mean it should be $100 \%$ clean and dry? Are there any margins for error? For example, do I need to wash a glass jar with detergent to remove the fatty content?

- What is the risk of sabotage to the recycling system if I sort packaging with mixed materials incorrectly?

We think there is a need for more information about the trade-off situations mentioned above, and for correct information about the preparation of the collected materials. Information about sorting is often printed on the packaging, but the consumers do not use it. The information is often hard to find and read, and sometimes difficult to follow, for example, the instruction to remove the metal clips 
from a plastic tube. Easy-to-follow symbols on the packaging could possibly increase recycling rates, but this requires the packaging design to allow for easy handling.

None of the respondents searched the web for more information. If they did, they would not find the information that they sought. The nationwide organisation that is responsible for the collection and recycling of packaging and newspapers, (FTI-Förpacknings- och Tidnings- Insamlingen) in Sweden, did not provide any answers to the questions above on their website at the time of the interviews, but recently updated their website with more information [49].

\subsection{Implications for Environmental Assessments}

This study shows that packaging and product functions influence the decisions of consumers to sort packaging into material recycling streams instead of letting them go into the mixed waste. However, this is not normally included in food-packaging life cycle assessments although they may have a profound influence on its environmental impact, as shown by Wikström et al. [31]. Earlier, for example, by Williams et al. [23] and Wikström et al. [30], the idea was advocated that user behaviour that influenced food waste ought to be included in the life cycle assessment of packaging, and this study underlines that the same principle is valid for user behaviour in recycling.

The question is how to accomplish this given that the knowledge of how packaging functions influence behaviour is under development, both qualitatively and quantitatively. Moreover, there are certainly significant differences among people and countries. At this stage, it is thought that the usage of scenario techniques, such as in [20] and [30], is a reasonable compromise between transparency and the ambition to improve the environmental assessment regarding recycling.

\subsection{Future Research}

This study has highlighted that the understanding of how different packaging functions and product properties influence consumers' recycling behaviour is an interesting area for increased understanding and research; however, it must be validated. With the experience from this study, the following suggestions are made:

- Blaming the packaging can be an effective way of making the respondents more honest, as they are less likely to feel blamed for a bad behaviour.

- To use pictures to trigger people's thoughts about packaging functions and recycling behaviour may be useful in much larger study-differentiated groups of households and within different geographical contexts. It is thought that this could be arranged with a survey to address a much larger group of people.

- Some of the factors that influence pro-environmental behaviour, as suggested by Kollmuss and Agyeman [25], should be further studied. What are the effects of changed internal factors, such as knowledge, values and attitudes, and changed external factors, such as the role of infrastructure with different collection systems and different economic situation?

- Since the respondents identified several obstacles for material recycling, there is a need to find out which functions influence the themes most and which themes have the highest impact. The importance of the themes can also be investigated in relation to the collection system.

\section{Conclusions}

The design of packaging functions influence consumers' convenience and their decision to put the used packaging into the recycling bin or the waste bin. This is an important factor in achieving the goals of a more circular economy from quantitative aspects, with more materials going into recycling, and from qualitative aspects, being cleaner in order to more often replace virgin materials. In the $\mathrm{EU}$, the Commission has suggested strengthening eco-design requirements in order to fully integrate end-of-life impacts. The method in this paper allows for a deeper understanding of the complex matter of decision-making with regard to packaging functions and also eliminates a degree of bias 
that can be expected in self-reported surveys. This study shows that a number of packaging functions can have a strong influence on consumers' decisions regarding whether or not to sort packaging for recycling. The respondents made quick assessments, for different packaging, of the environmental benefits of recycling, the work effort needed and the aspects of cleanliness. However, there is a need for further research in this area: both qualitative (as to what functions influence specific products) and quantitative (as to the degree of influence), to achieve a more thorough understanding of the results and in a wider population.

If the results can be demonstrated to be valid in a wider population, there is certainly a need to integrate this knowledge into packaging design, the environmental assessment of packaging and policymaking regarding recycling strategies [50].

Author Contributions: Conceptualisation, H.W., F.W. and K.W.-E.; data curation, H.W.; formal analysis, H.W., F.W., K.W.-E. and P.K.; funding acquisition, H.W.; methodology, H.W., F.W., K.W.-E. and P.K.; project administration, H.W.; validation, H.W. and K.W.-E.; visualisation, H.W., F.W. and K.W.-E.; writing—original draft, H.W. and F.W.; writing—review and editing, H.W., F.W., K.W.-E. and P.K.

Funding: This research was funded by BillerudKorsnäs $\mathrm{AB}$ and ÅForsk Foundation.

Acknowledgments: The authors wish to thank the participating respondents for their time and effort.

Conflicts of Interest: The authors declare no conflict of interest. The funders had no role in the design of the study; in the collection, analyses, or interpretation of data; in the writing of the manuscript; and in the decision to publish the results.

\section{References}

1. European Commission. Circular Economy: Closing the Loop. 2015. Available online: http://europa.eu/ rapid/press-release_IP-15-6203_en.htm (accessed on 18 June 2018).

2. Material Economics AB. Ett Värdebeständigt Svenskt Materialsystem. Stockholm, 2018. Available online: http:/ / databas.resource-sip.se/storage/vardebestmtrlsystemrapport180118.pdf (accessed on 18 June 2018).

3. Allerup, J.; Fråne, A. Sveriges Återvinning av Förpackningar och Tidningar. Uppföljning av Producentansvar för Förpackningar och Tidningar 2014. Naturvårdsverket, Sweden, 2015. Available online: https:/ / www.naturvardsverket.se/upload/stod-i-miljoarbetet/vagledning/avfall/forpackningar/ forpackningsrapport-2014-rev20160517.pdf (accessed on 18 June 2018).

4. Fråne, A.; Schmidt, L.; Sjöström, J.; Vukicevic, S.; Tapper, M. Kunskapsunderlag för Ökad Källsortering av Plastförpackningar; AB Rapport Nr B 2247; IVL Svenska Miljöinstitutet: Stockholm, Sweden, 2015. (In Swedish)

5. Cimpan, C.; Maul, A.; Jansen, M.; Pretz, T.; Wenzel, H. Central sorting and recovery of MSW recyclable materials: A review of technological state-of-the-art, cases, practice and implications for materials recycling. J. Environ. Manag. 2015, 156, 181-199. [CrossRef] [PubMed]

6. Barr, S.; Ford, N.J.; Gilg, A.W. Attitudes towards Recycling Household Waste in Exeter, Devon: Quantitative and qualitative approaches. Local Environ. 2003, 8, 407-421. [CrossRef]

7. Ando, Y.W; Gosselin, A.Y. Recycling in multifamily dwellings: Does convenience matter? Econ. Inq. 2005, 2, 426-438. [CrossRef]

8. Vining, J.; Ebreo, A. What makes a recycler? A comparison of recyclers and nonrecyclers. Environ. Behav. 1990, 22, 55-73. [CrossRef]

9. Lazarevic, D.E.; Aoustin, N.; Buclet, N.; Brandt, N. Plastic waste management in the context of a European recycling society: Comparing results and uncertainties in a life cycle perspective. Resour. Conserv. Recycl. 2010, 55, 246-259. [CrossRef]

10. Henriksson, G.; Åkesson, L.; Ewert, S. Uncertainty Regarding Waste Handling in Everyday Life. Sustainability 2010, 2, 2799-2813. [CrossRef]

11. Finnveden, G.; Ekvall, T.; Arushanyan, Y.; Bisaillon, M.; Henriksson, G.; Gunnarsson OÖstling, U.; Ljunggren Soöderman, M.; Sahlin, J.; Stenmarck, Å.; Sundberg, J.; et al. Policy Instruments towards a Sustainable Waste Management. Sustainability 2013, 5, 841-881. [CrossRef]

12. Perrin, D.; Barton, J. Issues associated with transforming household attitudes and opinions into materials recovery: A review of two kerbside recycling schemes. Resour. Conserv. Recycl. 2001, 33, 61-74. [CrossRef] 
13. Tonglet, M.; Phillips, P.; Read, A. Using the Theory of Planned Behaviour to investigate the determinants of recycling behaviour: A case study from Brixworth, UK. Resour. Conserv. Recycl. 2004, 41, 191-214. [CrossRef]

14. Sidique, S.; Joshi, S.; Lupi, F. Factors influencing the rate of recycling: An analysis of Minnesota counties. Resour. Conserv. Recycl. 2010, 54, 242-249. [CrossRef]

15. Martin, M.; Williams, I.D.; Clark, M. Social, cultural and structural influences on household waste recycling: A case study. Resour. Conserv. Recycl. 2006, 48, 357-395. [CrossRef]

16. Hage, O.; Söderholm, P.; Berglund, C. Norms and economic motivation in household recycling: Empirical evidence from Sweden. Resour. Conserv. Recycl. 2009, 53, 155-165. [CrossRef]

17. Klaiman, K.; Ortega, D.; Garnache, C. Perceived barriers to food packaging recycling: Evidence from a choice experiment of US consumers. Food Control. 2017, 73, 291-299. [CrossRef]

18. Lynch, D.; Kupper, F.; Broerse, J. Toward a Socially Desirable EU Research and Innovation Agenda on Urban Waste: A Transnational EU Citizen Consultation. Sustainability 2018, 10, 1641. [CrossRef]

19. Jelsma, J. Designing 'moralized' products. In User Behaviour and Technology Development; Verbeek, P.-P., Slob, A., Eds.; Springer: Dordrecht, The Netherlands, 2006; pp. 221-231.

20. Polizzi di Sorrentino, E.; Woelbert, E.; Sala, S. Consumers and their behavior: State of the art in behavioral science supporting use phase modeling in LCA and ecodesign. Int. J. Life Cycle Assess. 2016, 21, 237-251. [CrossRef]

21. Daae, J.; Boks, C. A classification of user research methods for design for sustainable behavior. J. Clean. Prod. 2015, 106, 680-689. [CrossRef]

22. Langley, J.; Turner, N.; Yoxall, A. Functions of packaging and influences on waste. Packag. Technol. Sci. 2011, 24, 161-175. [CrossRef]

23. Williams, H.; Wikström, F.; Otterbring, T.; Löfgren, M.; Gustafsson, A. Reasons for household food waste with special attention to packaging. J. Clean. Prod. 2012, 24, 141-148. [CrossRef]

24. Lindh, H.; Olsson, A.; Williams, H. Consumer perceptions of food packaging-Contributing to or counteracting environmentally sustainable development? Packag. Technol. Sci. 2016, 29, 3-23. [CrossRef]

25. Kollmuss, A.; Agyeman, J. Mind the Gap: Why do people act environmentally and what are the barriers to pro-environmental behavior? Environ. Educ. Res. 2002, 8, 239-260. [CrossRef]

26. Vargo, S.L.; Lusch, R.F. Evolving to a New Dominant Logic for Marketing. J. Mark. 2004, 68, 1-17. [CrossRef]

27. Edvardsson, B.; Kristensson, P.; Magnusson, P.; Sundström, E. Customer integration within service development-A review of methods and an analysis of insitu and exsitu contributions. Technovation 2012, 32, 419-429. [CrossRef]

28. Löfgren, M. Winning at the first and second moment of truth: An exploratory study. Manag. Serv. Qual. 2005, 15, 102-115. [CrossRef]

29. Williams, H.; Wikström, F.; Löfgren, M. A life-cycle perspective on environmental effects of customer focused packaging development. J. Clean. Prod. 2008, 16, 853-859. [CrossRef]

30. Wikström, F.; Williams, H.; Verghese, K.; Clune, S. The influence of packaging functions on consumer behaviour in food-packaging LCA studies-A neglected topic. J. Clean. Prod. 2014, 73, 100-108. [CrossRef]

31. Wikström, F.; Williams, H.; Govindarajan, V. The influence of packaging functions on recycling and food waste behavior-An environmental comparison of two packaging alternatives. J. Clean. Prod. 2016, 137, 895-902. [CrossRef]

32. Lindh, H.; Williams, H.; Olsson, A.; Wikström, F. Elucidating the indirect contributions of packaging to sustainable development-A terminology of packaging functions and features. Packag. Technol. Sci. 2016, 29, 225-246. [CrossRef]

33. Dahlén, L.; Lagerkvist, A. Methods for household waste composition studies. Waste Manag. 2008, 28, 1100-1112. [CrossRef] [PubMed]

34. Plumb, A.; Downing, P.; Parry, A. Consumer Attitudes to Food Waste and Food Packaging; WRAP: London, UK, 2013; ISBN 978-1-84405-465-7. Available online: www.wrap.org.uk (accessed on 18 June 2018).

35. González-Torre, P.; Adenso-Díaz, B. Influence of distance on the motivation and frequency of household recycling. Waste Manag. 2005, 25, 15-23. [CrossRef]

36. Wever, R.; Van Onselen, L.; Silvester, S.; Boks, C. Influence of packaging design on littering and waste behaviour. Packag. Technol. Sci. 2010, 23, 239-252. [CrossRef]

37. Crouch, M.; McKenzie, H. The logic of small samples in interview-based qualitative research. Soc. Sci. Inf. 2006, 45, 483-499. [CrossRef] 
38. Cross, N. Design research: A disciplined conversation. Des. Issues 1999, 15, 5-10. [CrossRef]

39. Simonsen, J.; Svabo, C.; Strandvad, S.M.; Samson, K.; Hertzum, M. (Eds.) Situated Design Methods; MIT Press: Cambridge, MA, USA, 2014; ISBN 9780262027632.

40. Visser, F.S.; Stappers, P.J.; Van der Lugt, R.; Sanders, E.B. Contextmapping: Experiences from practice. CoDesign 2005, 1, 119-149. [CrossRef]

41. Sanders, E.; Dandavate, U. Design for Experiencing: New Tools. In Proceedings of the First International Conference on Design and Emotion, TU Delft, The Netherlands, 3-5 November 1999.

42. Harper, D. Talking about pictures: A case for photo elicitation. Vis. Stud. 2002, 17, 13-26. [CrossRef]

43. Spradley, J.P. The Ethnographic Interview; Holt, Rinehart and Winston: New York, NY, USA, 1979; ISBN 10: 0030444969.

44. Kvale, S. Doing Interviews; Sage: Thousand Oaks, CA, USA, 2008; ISBN 9780761949770.

45. De Leon, J.; Cohen, J. Object and Walking Probes in Ethnographic Interviewing. Field Methods 2005, 17, 200-204. [CrossRef]

46. Singh, J.; Ordoñez, I. Resource recovery from post-consumer waste: Important lessons for the upcoming circular economy. J. Clean. Prod. 2016, 134, 342-353. [CrossRef]

47. Braun, V.; Clarke, V. Using thematic analysis in psychology. Qual. Res. Psychol. 2006, 3, 77-101. [CrossRef]

48. Hayes, N. Doing Qualitative Analysis in Psychology; Psychology Press/Erlbaum/Taylor \& Francis: Hove, UK, 1997.

49. FTIAB. Hushåll. 2. 2018. Available online: www.ftiab.se (accessed on 18 June 2018). (In Swedish)

50. European Parliament. Understanding Waste Streams. Treatment of Specific Waste. Briefing, 2015. Available online: http:/ / www.europarl.europa.eu/EPRS/EPRS-Briefing-564398-Understanding-wastestreams-FINAL.pdf (accessed on 28 June 2018).

(C) 2018 by the authors. Licensee MDPI, Basel, Switzerland. This article is an open access article distributed under the terms and conditions of the Creative Commons Attribution (CC BY) license (http:/ / creativecommons.org/licenses/by/4.0/). 